\title{
Level of Family Welfare with Part-Time Working Mothers
}

\author{
Lilies Yulastri ${ }^{1}$, Eti Herawati ${ }^{2}$, Dinda Aulia Syafira ${ }^{3}$, Ayu Lestari $^{4}$ \\ \{liliesyulastri@yahoo.com $\}$
}

Beauty Department, Universitas Negeri Jakarta, Indonesia ${ }^{1234}$

\begin{abstract}
This research discusses the extent of the family welfare with mothers who work part-time, to find out the level of welfare of the family by looking at formal education that taken by the head of the family in where the head of the Family is main support of the economy in family, then in this study also looked at how the use of the family income could meet the needs of the family. In addition, also to find out the extent of the housewives' contribution who help with additional income in meeting the needs of their families. The research technique is through descriptive of analytics with a cross sectional approach, in this modeling all variables are considered important so that it can be estimated several regression coefficients $(\beta)$ at once. The study data was obtained from 100 respondents. With the total number of questions as many as 35 questions that have gone through the validity and reliability test. This research was conducted in DKI Jakarta with the spread of 5 areas of DKI Jakarta namely east Jakarta, South Jakarta, west Jakarta, Central Jakarta and North Jakarta. Based on the results of hypothetical testing that has been done proven that there is a positive relationship between the mother's housewives who working part-time and the welfare of the Family. This statement can be interpreted as rejecting $\mathrm{Ho}$ and accepting Ha. The two variables have a positive relationship. This shows that the better of value of housewives who working part-time, the better the welfare of your family and vice versa if the value of working part-time mothers is low, the lower the welfare of the family. To test the hypothesis, a prerequisite test of analysis is a normality test and a data reliability test. Based on the calculation of normality test obtained significance (P Value) family welfare variable of 0.660 so that the significant value of the family environment variable is greater than 0.05 which means normal distributed data. As for the significance value (P Value) for variable mothers working part-time of 0720 . The significant value of a part-time working mother variable is greater than 0.05 which means normal distributed data. The Contribution of Housewives working part-time to family health in DKI Jakarta. Variable free X, parttime mother as shown in Table 5.4. seen in the Summary model table, the number $\mathrm{R}$ Square $=0.548$ as a determinant coefficient, which in this case means that $54.8 \%$ means family well-being is influenced by working mothers at $54.8 \%$, while $45.2 \%$ is influenced by other factors, In this case the contribution of part-time working housewives is $54.8 \%$ to family welfare.
\end{abstract}

Keywords: Family Welfare; Housewives; DKI Jakarta

\section{Introduction}

The Susilo Bambang Yudhoyono-Boediono government is targeting poverty levels to reach 8-10 percent by the end of 2014. In achieving this target, the Government implements 
poverty alleviation programs which are grouped into 3 clusters. The first cluster is familybased poverty reduction programs, such as health assistance, education, and also the family hope program $(\mathrm{PKH})$. It was explained that in low-income people the income they get is only enough to meet basic needs, even they are no longer able to meet the needs of life properly, so the quality of family life is felt to decline and this has a negative impact on the level of community welfare. However, not all poverty is synonymous with inequality, as well as a high level of income does not reflect a high level of welfare.

There are many definitions of contribution, some mean the contribution or role or participation of a person in a particular activity. They interpret contributions according to their respective perspectives. Contribution comes from English, namely Contribute, contribution, which means participation, involvement, involvement and contribution. Contribution in the sense of action is an individual action that can have a positive or negative impact on others. By contributing, it means that individuals try to improve the efficiency and effectiveness of their lives. The definition of contribution for part-time housewives is the extent to which the portion or result of the housewife's work is in the form of funds collected compared to the total income / income obtained in a family, in addition to the income from the head of the family. The income of the housewife is the participation of a housewife who works part time, meaning that she does not work a full day like a woman working in an office or institution that requires working according to the hours set by her institution, meaning that the housewife only works a few hours of the day.

Part-time work is regular, voluntary work where hours are substantially shorter than standard hours of work. Based on Law no. 13 of 2003 (Chapter IX, article 56) concerning Manpower, the types of work agreement (contract) can be divided into 2 (two), namely: (1) work agreement (contract) for a certain period of time; (2) an indefinite work agreement (contract) (RI Law No.13 of 2003 on Manpower). The above jobs are included in the type of work agreement (contract) for a certain time, because they are made for work which according to the type, nature and activity of the work will be completed within a certain time. Housewife is a term used for a woman who is married and carries out household chores. According to Hardjito Notopuro (1984: 46).

\subsection{Mother's Reason for Working}

According to Williams in Lemme (1995) women are motivated to work for three reasons, namely: Economic needs, often large and urgent household needs, make mothers have to work to fulfill their daily needs, there are certain aspects of their role in the family that motivate them to look for alternative activities besides being at home (such as boredom), Fulfill psychological needs such as social contact, realize the potential and desire to benefit the environment. Hoffman (1984) in his book entitled Working Mothers: An Evaluate Review of the Consequences for wife, husband and child, mentions several factors that influence a mother's decision to work: Economic Needs. There are many motives that underlie this factor, depending on the conditions and circumstances of the family. The husband's insufficient income is often the biggest motive. But there are other motives, such as mothers wanting valuables that require more money to buy them, because that is why mothers work.

Housework (the role of housewife) which gradually becomes no longer satisfying, boring and does not require skills. Especially when the smallest child has started to enter school, so often mothers feel they are no longer needed at home (Birnbaum, 1971) Personality. For example, the need for achievement, being valued because of their higher status, the desire to be of benefit to the environment and also to use their potential. There are several things that 
cause women to play a role in the family economy, namely because there is support from their husbands because their income cannot meet family needs, cultural factors, social factors, factors where women socialize in accordance with existing norms in society and finally religious factors. Community welfare can be realized if there are efforts to meet physical and spiritual needs. The balance between physical and spiritual needs or the harmony between the two is called welfare. Achievement of physical needs can be measured using material benchmarks, where each individual has different sizes according to his abilities. Some are online matter can reach very high levels if measured by physical requirements, but some fall below the minimum size line.

\subsection{Factors Affecting the Level of Welfare}

It is known that welfare can be obtained if there is a balance or harmony between the fulfillment of physical needs and spiritual needs. The Indonesian Central Bureau of Statistics (2000) explains that to see the level of household welfare in an area, several indicators are used as a measure, including: Family income level, Composition of household expenditure by comparing expenditure on food and non-food, Family education level, Family health level, and Housing conditions and facilities owned in the household.

\section{Methodology}

The research design was cross sectional. The research was conducted in DKI Jakarta. Data collection was carried out for 2 months from August to September 2020. Research variable the variables in this study are: The independent variable is the housewife, ladder who work part time (X1) The dependent variable is family welfare (Y), Predecessor variables: age, type of work, level of education, number of family dependents, less household income or equivalent to UMP encourages housewives to work part time. The research sample was 100 people from the DKI Jakarta area. The research instrument is a tool used to measure observed natural and social phenomena. Sugiyono (2010: 102) The instrument used in the study was the family welfare instrument.

The research instrument used to collect data in this study was a questionnaire / questionnaire. So that the instrument used is in accordance with the aspects being measured, the making of the instrument is done through the arrangement of the instrument grid. Details regarding the arrangement of the instrument lattice can be seen in the Variable welfare family lattice matrix table. The data collected is primary data obtained through a survey using a questionnaire and a questionnaire filled out directly by the respondent. Data collection was carried out for 4 weeks in April-August 2020. In the implementation of data collection, the researcher used 2 enumerators. Before the enumerators collected data, the enumerators were given directions and instructions by the researcher regarding the steps that had to be taken by the enumerators at the time of data collection. The form of direction given to the enumerator is as follows: Was given instructions on how to fill out the questionnaire and explain each item of the question, Instructions are given on how to deal with respondents when explaining the implementation of the questionnaire trial, After the enumerators were given directions and directions, they conducted a questionnaire trial for 20 part-time workers.

In the implementation before the instrument is distributed to the respondents, the questionnaire / questionnaire is tested first, namely testing the validity and reliability of the 
three instruments. Validity test is used to measure whether a questionnaire is valid or not. A questionnaire is said to be valid if the questions on the questionnaire are able to reveal something that will be measured by the questionnaire. The validity test was calculated by comparing the calculated $r$ value (correlated item-total correlation) with the $r$ table value. If $r$ count> $r$ table and the value is positive then the item or question is declared valid (Ghozali, 2005), while the reliability test is data to measure a questionnaire which is an indicator of a variable or construct. A questionnaire is said to be reliable or reliable if a person's answer to a statement is consistent or stable over time. Reliability concerning the consistency of answers if tested repeatedly on different samples. SPSS provides facilities for measuring reliability with the Cronbach Alpha (á) statistical test.

\section{Result and Discussion}

In one study conducted by Uci Yulianti from UMM Malang 2019, generally obtained on hypothetical test results that prove a positive relationship between working part-time mothers and family welfare. This statement can be interpreted as rejecting Ho and accepting Ha. The two variables have a positive relationship. This shows that the better the value of working part-time mothers, the better the welfare of your family and vice versa if the value of working part-time will be lower for the welfare of the family. This research is a custodia research with survey method, so the data obtained comes from the filling of questionnaire instruments distributed to respondents., through the questionnaire spread the questionnaire to 100 respondents who are part-time working mothers. Welfare is a condition in which a person can meet basic needs, be it the need for food, clothing, shelter, clean drinking water and the opportunity to continue his education and have an adequate job that can support his quality of life so that his life is free from poverty, ignorance, fear, or worry so that his life is safe, both born and mental. (Fahrudin, 2012).

Referring to the book Indicators of Prosperous Families (Sunarti Eui, IPB 2006), Family welfare (tied variables) in this study was measured by 6 indicators that hinted at a part-time working mother, where from the results of the study obtained variable $Y$ through questionnaire, known that the minimum score of mothers who working part-time is 35 and the maximum score is 62. Standard deviation of 6,698. range of 27. Working part-time (free variables) in this study were measured by 8 indicators namely Family Needs Fulfillment, Food, Housing, health, recreation, Interaction in the family, social interaction with the environment, Information and Communication Needs and role in the family. from the filling out of the $\mathrm{X}$ variable questionnaire, it is known that the minimum family welfare score is 14 and the maximum score is 28 . Standard deviation of 2,730, and range of 14 .

To test the hypothesis, a prerequisite test of analysis is a normality test and a data reliability test. Based on the calculation of normality test obtained significance ( $\mathrm{P}$ Value) family welfare variable of 0.660 so that the significant value of the family environment variable is greater than 0.05 which means normal distributed data. As for the significance value ( $\mathrm{P}$ Value) for variable mothers working part-time of 0.720 . The significant value of a part-time working mother variable is greater than 0.05 which means normal distributed data. The significance of the two variables is said to have a linear relationship when the linear significance value is less than 0.05 based on the calculation results that have been performed, obtained a value of $\mathrm{P}$ value of 0.021 which means less than 0.05 which means linear patterned data. Hypothetical testing in this study, proving that there is a positive relationship between 
the family environment and the motivation of learning the life skills of Makeup. The data analysis showed that the correlation coefficient ( $\mathrm{r}$ ) value of $0.633 \mathrm{had}$ a strong relationship between the family environment and learning motivation.

From linear regression test results obtained results that there is a positive relationship between working part-time mothers $(\mathrm{X})$ and Family Welfare $(\mathrm{Y})$ this is obtained from calculations using simple linear regression with a value of $\mathrm{P}$ value of 0.00 where $\mathrm{H} 0$ is rejected if $\mathrm{P}_{\text {value }}<\alpha 5 \%$ i.e., $0.00<0.00$. and the relationship shows a strong relationship where the value of $r$ is 0.74 between the mother working part-time with the Welfare of the Family, as well as the direct and positive. Receiving Ha which means there is a relationship of part-time working mothers with the welfare of family / The result of the calculation of regression equation, based on the explanation, the regression line equation between the two variables is $\mathrm{Y}=10,129+1,817$ Part-Time Working Mothers. The regression coefficient of 10,129 states that every increase in mothers working part-time, there will be an increase in learning outcomes by 10,129 times.

The Contribution of Housewives who working part-time to family health in DKI Jakarta. Variable free X, part-time mother as shown in Table 5.4. seen in the Summary model table, the number $\mathrm{R}$ Square $=0.548$ as a determinant coefficient, which in this case means that $54.8 \%$ means family well-being is influenced by working mothers at $54.8 \%$, while $45.2 \%$ is influenced by other factors, in this case the contribution of part-time working housewives is $54.8 \%$ to family welfare.

\section{Conclusion}

Family welfare is a reflection of people's well-being. The welfare of the community means a reflection of social welfare. The term welfare has a fairly broad meaning. Welfare is not only about outward or material aspects, but also mental or spiritual. Welfare is often synonymous with prosperity. Happiness of life as well as a good quality of life. Based on the results of hypothetical testing that has been done proven that there is a positive relationship between the mother working part-time and the welfare of the Family. This statement can be interpreted as rejecting Ho and accepting Ha. The two variables have a positive relationship. This shows that the better the value of working part-time mothers, the better the welfare of your family and vice versa if the value of working part-time mothers is low, the lower the welfare of the family.

The Contribution of Housewives who working part-time to family health in DKI Jakarta. Variable free X, part-time mother as shown in Table 5.4. seen in the Summary model table, the number $\mathrm{R}$ Square $=0.548$ as a determinant coefficient, which in this case means that $54.8 \%$ means family well-being is influenced by working mothers at $54.8 \%$, while $45.2 \%$ is influenced by other factors, in this case the contribution of part-time working housewives is $54.8 \%$ to family welfare. Based on the testing that has been done, concluded that the contribution of housewives working part-time to the welfare of the family is significant by rejecting $\mathrm{H} 0$ and receiving $\mathrm{H} 1$. Based on the tests that have been done, it is concluded that the contribution of part-time housewives to family welfare is significant by rejecting $\mathrm{HO}$ and accepting $\mathrm{H} 1$. 


\section{References}

[1] Abu, Ahmadi. 2003. Ilmu Sosial Dasar. Jakarta: Rineka Cipta.

[2] Adi, Fahrudin. 2012. Pengantar Kesejahteraan Sosial. Bandung: PT. Refika Aditama.

[3] BPS. 2000. Statitik Indonesia 2000. Jakarta: BPS.

[4] Edi, Suharto. 2005. Membangun Masyarakat Memberdayakan Rakyat (Kajian Strategis Pembangunan Kesejahteraan Sosial dan Pekerjaan Sosial. Bandung: Refika Aditama.

[5] Fadhil, Nurdin. 1990. Pengantar Studi Kesejahteraan Sosial. Bandung: PT. Angkasa.

[6] Kementerian Komunikasi dan Informatika RI. 2011. Program Penanggulangan Kemiskinan Kabinet Indonesia Bersatu 2.

[7] Kholid, Narbuko. 2013. Metodologi Penelitian. Jakarta: Bumi Aksara.

[8] Lexi J, Moleong. 1999. Metodologi Penelitian Kualitatif. Bandung: PT. Remaja Rosdakarya.

[9] Shinta, Doriza. 2015. Ekonomi Keluarga. Bandung: PT. Remaja Rosdakarya.

[10] Tim Nasional Percepatan Penanggulangan Kemiskinan (TNP2K). 2010. Indikator Kesejahteraan Rakyat Buku 2: Pendidikan. Jakarta.

[11] Undang-Undang Republik Indonesia Nomor 52 Tahun 2009. Perkembangan Kependudukan dan Pembangunan Keluarga.

[12] Jenjang Pendidikan Formal di Indonesia Menurut Undang-undang Sistem Pendidikan Nasional Tahun 2003. Diunduh dari http://ilmu-pendidikan.net/pendidikan/peraturan/ieniangpendidikan-formal-di-indonesia-uu-sisdiknas-2003 akses tanggal 22 April 2016.

[13] Pendidikan Untuk Kesejahteraan. Diunduh dari http://www.republika.co.id/ berita/kolom/resonansi/14/03/18/n2mpo8-pendidikan-untuk-keseiahteraan akses tanggal 22 April 2016. 